\title{
Teacher Supervision in the Context of Linguistic Diversity in OECD Countries
}

\author{
Yesifa Azovide, Yamina Bouchamma \\ Université Laval, Québec, Canada \\ Email: koudjo-afuwu-yesifa.azovide.1@ulaval.ca, yamina.bouchamma@fse.ulaval.ca
}

How to cite this paper: Azovide, Y., \& Bouchamma, Y. (2021). Teacher Supervision in the Context of Linguistic Diversity in OECD Countries. Creative Education, 12, 1103-1117.

https://doi.org/10.4236/ce.2021.125082

Received: April 15, 2021

Accepted: May 25, 2021

Published: May 28, 2021

Copyright $\odot 2021$ by author(s) and Scientific Research Publishing Inc. This work is licensed under the Creative Commons Attribution International License (CC BY 4.0).

http://creativecommons.org/licenses/by/4.0/

\begin{abstract}
This study addresses teacher supervision in a context of linguistic diversity using data from the OECD's Teaching and Learning International Survey (TALIS, 2013) in which school leaders $(\mathrm{N}=7438)$ from 36 OCDE-member countries participated. Factor analyses on the principals' supervision practices enabled us to identify three forms of supervision: administrative, pedagogical, and professional (career development). Kendall tau-b correlations revealed that the principals' administrative and career development supervision correlated with the linguistic diversity of the students. Also discussed is the impact of this linguistic diversity on the administrative supervision provided and the teacher professional development.
\end{abstract}

\section{Keywords}

Supervision in a Context of Linguistic Diversity, Students' Linguistic Diversity, Principals' Administrative Supervision,

Principals' Career Development Supervision, Teacher Professional Development, OECD's Teaching and Learning International Survey (TALIS, 2013)

\section{Introduction}

With significant human migratory movements on the rise, the portrait of welcoming societies and their schools has considerably changed (Castles, 2010; Czaika \& De Haas, 2014; De Witte, 2018; Goldin, Cameron, \& Balarajan, 2011; Hall \& Posel, 2019; Koser, 2016; OECD, 2018; Triandafyllidou, 2018). In this context, schools in many countries must therefore compose with the cultural and linguistic diversity of their students (Appave \& David, 2017; Castles et al., 2002; Commission européenne, 2018; Demireva, 2017; OECD, 2018; Newland, 2017; Silver, 2015; Somers, 2018; Zetter et al., 2006), resulting in additional tasks for both principals and teachers. In OECD-member countries, improving stu- 
dent achievement and the performance of multicultural schools is notably achieved through the principal's Supervision of their teachers' professional growth (OECD, 2018; Somers, 2018; Panagiotopoulou \& Rosen, 2018).

In order to respond effectively to the specific needs of immigrant-origin youth, teachers must pursue continuous professional development using pedagogical practices associated with intercultural education (UNESCO, 2017). Indeed, teachers in many education systems agree that they need to grow professionally to better meet the challenges of teaching immigrant-origin students (OECD, 2018; UNESCO, 2017; Brown \& Medway, 2007; McAndrew, 2001) and that their principal plays a key role in this process (OECD, 2018).

It is well established that school leaders are responsible for teacher supervision as part of their current pedagogical practices exercised in today's schools (L'Hostie \& Boucher, 2004). Their leadership directly influences the general effectiveness of the school, the teachers' motivation and commitment, the working conditions, the delegation of power within the organization, and the school's culture (Bouchamma, 2011; Collerette, Pelletier, \& Turcotte, 2013; Hallinger \& Heck, 1998; Marzano, Waters, \& McNulty, 2005; Pont, Nusche, \& Moorman, 2008; Robinson, 2007; Spanneut, 2010). And yet, despite the emergence of inclusive education in several countries, the principal's leadership remains far from understood in contexts of diversity (Bouchamma, 2008, 2011; Lambert \& Bouchamma, 2019). The study of Branch, Hanushek and Rivkin (2012) noted the low presence of quantitative studies in the field of leadership, despite its effect on academic success. Thus, it seems relevant to contribute to knowledge on this topic with quantitative studies.

\section{Review of the Literature}

Leadership signifies exercising a regular and repetitive influence to stimulate and encourage collaboration in group actions (Hallinger \& Heck, 1998; Marzano, Waters, \& McNulty, 2005; Northouse, 2012; Pont, Nusche, \& Moorman, 2008; Robinson, Lloyd \& Rowe, 2008; Robinson, 2007; Spanneut, 2010). Specifically, pedagogical leadership and transformational leadership are characterized by regularly scheduled meetings and practices that are adopted before, during, and after the process, with teaching-related discussions centered on providing constructive feedback to the teacher (Marshall, 2005; Bouchamma, 2005; DuFour, DuFour \& Eaker, 2004; Nolan \& Hoover, 2008; Sergiovanni \& Starratt, 2013; Silva \& Dana, 2001).

Studies have indeed demonstrated the positive effect of principals' practices on both teaching and student learning and notably on motivation and involvement, teachers' perceptions, and the climate they establish in the school (Leithwood \& Jantzi, 2006, 2008; Leithwood et al., 2004). For example, in their study of several meta-analyses, Pont, Nusche, and Moorman (2008) identified five leadership practices of principals that contributed significantly to improving teaching and learning: enhanced teacher quality, clearly defined and coherent 
objectives, students' measured outcomes, guaranteed resources, and collaboration with partners in the community.

Although the relevance of pedagogical leadership has been widely acknowledged in the literature, the pre-service training of principals on this aspect is relatively recent and the required competencies in these training profiles are either incomplete or require updating, as has been observed in Québec's education leadership profiles. Specifically, in the competency standards for school leaders in Alberta, Australia, and the United States, diversity management is addressed, yet it is absent in the Québec profiles (Bouchamma \& Lambert, 2019; OECD, 2018). The present study therefore explores two key concepts, namely, teacher supervision practices and students' linguistic diversity.

\subsection{Pedagogical Supervision Practices}

Principals' teacher supervision practices are not viewed here a summative evaluation for recruitment or promotion purposes, but rather as effective guidance and supervision provided to teachers to facilitate and supervision pedagogical adjustments to best address the needs of the students (Leithwood, Harris, \& Hopkins, 2008; Nolan \& Hoover, 2008; Sergiovanni \& Starratt, 2013). Notable actions include the elaboration, development, and coordination of teaching plans and educational programs and the determination and supervision of high-performance teaching standards through targeted facilitation for both teachers and their teaching practices during regularly scheduled meetings (Bouchamma, 2005; Cotton, 2003; Lapointe \& Archambault, 2005; Marshall, 2005; Nolan \& Hoover, 2008; Silva \& Dana, 2001).

\subsection{Students' Linguistic Diversity}

The school is known to reflect certain societal aspects (Castles, 2010; Czaika \& De Haas, 2014; Demireva, 2017; De Witte, 2018; Goldin, Cameron, \& Balarajan, 2011; Hall \& Posel, 2019; Koser, 2016; OECD, 2018; Silver, 2015; Triandafyllidou, 2018). In order to manage this diversity, principals are called upon to supervise their teachers' pedagogy-driven practices and impose effective supervision measures in this regard (Appave \& David, 2017; OECD, 2018; Panagiotopoulou \& Rosen, 2018; Somers, 2018).

\subsection{Objectives}

Because principals' teacher supervision practices-although extensively researched-remain undocumented in the presence of student linguistic diversity (Bouchamma, 2008, 2011; Bouchamma \& Lambert, 2018), we sought to gain knowledge on these supervision practices in such a context while considering the principals' sociodemographic and socioprofessional characteristics and those pertaining to their school. Thus, this study aims to determine the nature of the links between the linguistic diversity of students at school and the pedagogical supervision and support practices of teachers. 


\section{Methodology}

\subsection{Data Sources and Participants}

We used TALIS 2013 data gathered from a questionnaire administered to school principals $(\mathrm{N}=7438)$ from 36 member-countries of the Organisation for Economic Co-operation and Development (OECD). The questionnaire housed 39 questions on the subject of linguistic diversity in schools (percentage of schools in which students whose [first language] is different from the language(s) of instruction or from a dialect of this/ these languages( $s)$ ) and the principals' personal and professional characteristics and teacher supervision practices in these OECD-member countries. Data from questions 1, 9, 10, 15A, 21, and 29 describe the professional development supervision provided by the principals to their teachers in contexts involving student linguistic diversity.

\subsection{Sample}

The participating principals hailed from 204 schools of OECD-member countries (TALIS, 2013). Of these participants, $87.2 \%(\mathrm{~N}=5979)$ had been trained in School administration or principal training programme or course, while $91.6 \%$ $(\mathrm{N}=6128)$ had acquired Formal education/Teacher training/education programme or course, and 79.6\% $(\mathrm{N}=5330)$ had benefited from Formal education/Instructional leadership training or course before and/or after entering the profession as principal.

Females accounted for $49.7 \%(\mathrm{~N}=3692)$ of the participants and males accounted for $45.3 \%(\mathrm{~N}=3371)$ of the total sample of schools presenting the following characteristics pertaining to linguistic diversity (Table 1).

Table 1. Presence of students' linguistic diversity.

\begin{tabular}{ccc}
\hline Level of linguistic diversity & Frequency & Percentage \\
\hline Absent & 3025 & 40.7 \\
Weak & 2697 & 36.3 \\
Average & 614 & 8.3 \\
Strong & 264 & 3.6 \\
Very strong & 310 & 4.2 \\
\hline
\end{tabular}

$\mathrm{N}=7438$.

\subsection{Variables}

Following a factor analysis of questions 21 and 29, we identified three dependent variables defining the type of supervision given by the principals to their teachers (see Table 2): 1) administrative supervision; 2) pedagogical supervision; and 3) career development supervision. Our independent variables were the linguistic diversity of the students, sociodemographic (principals gender), socioprofessional (training in School administration or principal training programme or course; Formal education/teacher training or course; Formal education/instructional 
leadership training or course, experience as principal in this school and overall), and contextual characteristics (type of school management, school s location).

Table 2. Principals' teacher supervision practices (Questions 21 and 29).

\begin{tabular}{|c|c|c|c|}
\hline \multirow[b]{2}{*}{ Items } & \multicolumn{3}{|c|}{ Factors } \\
\hline & $\begin{array}{l}\text { Administrative } \\
\text { supervision }\end{array}$ & $\begin{array}{l}\text { Pedagogical } \\
\text { supervision }\end{array}$ & $\begin{array}{c}\text { Career } \\
\text { Development } \\
\text { supervision }\end{array}$ \\
\hline \multicolumn{4}{|l|}{ The principals: } \\
\hline $21 \mathrm{H}$ Resolved problems with the lessons timetable & 0.721 & & \\
\hline $\begin{array}{l}\text { 21A Collaborated with teachers to solve discipline } \\
\text { problems }\end{array}$ & 0.691 & & \\
\hline 21G Checked for mistakes in school procedures & 0.666 & & \\
\hline 21F Provided parents or guardians with information & 0.597 & & \\
\hline 21C Supported co-operation among teachers & 0.518 & & \\
\hline $\begin{array}{l}\text { 29B Development or training plan is developed for } \\
\text { each teacher }\end{array}$ & & 0.702 & \\
\hline $\begin{array}{l}\text { 29A Measures to remedy any weaknesses in teaching } \\
\text { are discussed }\end{array}$ & & 0.633 & \\
\hline $\begin{array}{l}\text { 21D Teachers responsibility for improving teaching } \\
\text { skills }\end{array}$ & & 0.591 & \\
\hline $\begin{array}{l}\text { 29D Mentor is appointed to help the teacher } \\
\text { improve his/her teaching }\end{array}$ & & 0.564 & \\
\hline $\begin{array}{l}29 \mathrm{~F} \text { Change in a teacher's salary or a payment of a } \\
\text { financial bonus }\end{array}$ & & & 0.746 \\
\hline $\begin{array}{l}\text { 29G Change in the likelihood of a teacher's career } \\
\text { advancement }\end{array}$ & & & 0.680 \\
\hline $\begin{array}{l}29 \mathrm{C} \text { Material sanctions such as reduced annual } \\
\text { increases in pay are imposed }\end{array}$ & & & 0.636 \\
\hline 29E Change in a teacher's work responsibilities & & & 0.575 \\
\hline 29H Dismissal or non-renewal of contract & & & 0.574 \\
\hline
\end{tabular}

\subsection{Data Analysis}

SPSS 27 software was used to analyze the data. Since our variables were ordinal categorical (Cohen, 1992, 2013), we performed a Kendall's tau-b correlation analysis to examine the relationships between the linguistic diversity of the students, and certain relevant sociodemographic (principals' gender), socioprofessional (training in School administration or principal training programme or course, Formal education/teacher training or course, Formal education/instructional leadership training or course); and experience as principal in this school and overall), and contextual characteristics (type of school management, school's location). This was also justified by the fact that school principals' practices can be grouped hierarchically according to all independent variables selected in our study. 


\section{Results}

\subsection{Factor Analysis Results}

Table 2 shows that the factor analysis of 17 items associated with the different types of teacher supervision practices used by principals (questions 21 and 29) produced three factors explaining $44.523 \%$ of the total variance.

The most significant factor was "Administrative supervision", which alone explained $22.988 \%$ of the total variance and consisted of items 21A (collaborated with teachers to solve discipline problems), 21C (supported co-operation among teachers), $21 \mathrm{~F}$ (provided parents or guardians with information), 21G (checked for mistakes in school procedures), and $21 \mathrm{H}$ (resolved problems with the lessons timetable.

The second most significant factor was "Pedagogical supervision", which explained $14.318 \%$ of the total variance. This factor housed items 21D (teachers responsibility for improving teaching skills), 29A (measures to remedy any weaknesses in teaching are discussed), 29B (development or training plan is developed for each teacher), and 29D (mentor is appointed to help the teacher improve his/ her teaching).

The third most notable factor, "Career development supervision", explained $7.216 \%$ of the total variance and consisted of items 29C (material sanctions such as reduced annual increases in pay are imposed), 29E (change in a teacher's work responsibilities), 29F (change in a teacher's salary or a payment of a financial bonus), 29G (change in the likelihood of a teacher's career advancement), and $29 \mathrm{H}$ (dismissal or non-renewal of contract). The Kaiser-Meyer-Olkin measure of sampling adequacy was 0.839 , which was excellent as it was above 0.5, while the obtained Cronbach's alpha for all 17 items of questions 21 and 29 was 0.770 , which was also considered excellent, as it was above 0.6.

The retained independent variables included the principals' sociodemographic (gender) and socioprofessional characteristics (formal education/school administration or principal training programme or course, formal education/teacher training/education programme or course, formal education/instructional leadership training or course, experiencel year(s) working as a principal at this schooll year(s) working as a principal in total), school-related contextual determinants publiclyl privately managed school, schools location), and finally the amount of student linguistic diversity (percentage of students whose [first language] is different from the language(s) of instruction or from a dialect of this/ these languages $(s))$, as measured on a scale ranging from "absent" $(0 \%)$ to "very strong" (60\% or more) on item A of question 15.

\subsection{Correlations}

A correlation analysis was conducted to determine correlations between the principals' supervision practices, the students' linguistic diversity, the principals' sociodemographic and socioprofessional characteristics, and the contextual characteristics of their schools. 
Table 3. Correlations between the three types of teacher supervision and the principals' sociodemographic and socioprofessional characteristics and those of their school and students.

\begin{tabular}{|c|c|c|c|c|c|c|c|c|c|c|c|c|}
\hline Variables & 1 & 2 & 3 & 4 & 5 & 6 & 7 & 8 & 9 & 10 & 11 & 12 \\
\hline 1. Administrative supervision & - & & & & & & & & & & & \\
\hline 2. Pedagogical supervision & -0.001 & - & & & & & & & & & & \\
\hline 3. Career development supervision & $-0.026^{\star *}$ & -0.007 & - & & & & & & & & & \\
\hline 4. Students' linguistic diversity & $-0.112^{\star *}$ & -0.007 & $0.068^{* *}$ & - & & & & & & & & \\
\hline 5. School's location & $-0.044^{\star *}$ & $0.119^{* *}$ & $0.056^{\star *}$ & $0.101^{* *}$ & - & & & & & & & \\
\hline 6. Public or private school & $-0.085^{\star *}$ & $+0.022^{*}$ & $0.087^{* *}$ & $0.060^{* *}$ & $0.145^{\star *}$ & - & & & & & & \\
\hline 7. Principal's gender & $-0.092^{* *}$ & $-0.088^{\star *}$ & -0.015 & 0.018 & $0.029^{\star *}$ & $0.056^{* *}$ & - & & & & & \\
\hline $\begin{array}{l}\text { 8. Formal education/School } \\
\text { administration or principal training } \\
\text { programme or course }\end{array}$ & 0.000 & $-0.021^{*}$ & $-0.054^{\star *}$ & -0.013 & $-0.057^{\star \star}$ & $0.045^{\star *}$ & -0.009 & - & & & & \\
\hline $\begin{array}{l}\text { 9. Formal education/Teacher training/ } \\
\text { education programme or course }\end{array}$ & $0.023^{*}$ & $-0.055^{\star *}$ & $-0.058^{\star *}$ & $-0.061^{* *}$ & $*-0.040^{* *}$ & 0.011 & -0.018 & $0.407^{\star *}$ & - & & & \\
\hline $\begin{array}{l}\text { 10. Formal education/Instructional } \\
\text { leadership training or course }\end{array}$ & -0.002 & $-0.076^{\star *}$ & $* 0.055^{\star *}$ & $-0.048^{* *}$ & ${ }^{\star}-0.068^{\star *}$ & -0.017 & $-0.025^{\star}$ & $0.467^{\star *}$ & $0.501^{* *}$ & - & & \\
\hline $\begin{array}{l}\text { 11. Experience/Number of year(s) as } \\
\text { principal at this school }\end{array}$ & -0.017 & $-0.022^{\star}$ & 0.014 & $0.035^{\star \star}$ & -0.002 & 0.006 & 0.009 & $-0.051^{\star \star}$ & $-0.040^{\star *}$ & $0.040^{\star \star}$ & - & \\
\hline $\begin{array}{l}\text { 12. Overall experience/Number of } \\
\text { year(s) in the profession as principal }\end{array}$ & -0.015 & -0.003 & 0.015 & 0.015 & 0.012 & -0.011 & 0.008 & $-0.063^{\star *}$ & $-0.052^{\star *}$ & $0.052^{* *}$ & $0.637^{\star *}$ & - \\
\hline
\end{tabular}

Note: ${ }^{\star} p<0.05 ;{ }^{*} p<0.01$. 
- the principal was female.

Weak, positive, but significant correlations were observed between administrative supervision and Formal education/Teacher training/education programme or course $(\tau=0.023 ; p<0.05)$, indicating that administrative supervision increased when the principal had benefited from Formal education/Teacher training/education or course before and/or after becoming principal.

Weak, negative, but significant correlations were observed between the principals' pedagogical supervision for their teachers and the following:

- Gender of the principal $(\tau=-0.088 ; p<0.01)$ : Pedagogical supervision decreased when the principal was male.

- Training in School administration or principal training programme or course ( $\tau=-0.021 ; p<0.05)$ : Pedagogical supervision decreased when the principal was shown to have had this training before and/or after becoming principal.

- Formal education/Teacher training/education programme or course $(\tau=$ -0.055; $p<0.01)$ : Pedagogical supervision decreased when the principal had acquired this training before and/or after becoming principal.

- Formal education/Instructional leadership training or course $(\tau=-0.076 ; p<$ 0.01): Pedagogical supervision decreased when the principal had received this training before and/or after becoming principal.

- Experience as principal in this school $(\tau=-0.022 ; p<0.05)$ : Pedagogical supervision decreased when the Number of years of experience as principal in the current school increased.

However, pedagogical supervision was shown to increase when the principals:

- were female;

- had no Training in School administration or principal training programme or course before and/or after becoming principal;

- had no Formal education/Teacher training/education programme or course before and/or after becoming principal;

- had no Formal education/Instructional leadership training or course;

- when their experience as principal in this school decreased.

Weak, positive, but significant correlations were observed between pedagogical supervision and:

- schools location ( $\tau=0.119 ; p<0.01$ ): Pedagogical supervision increased when the school was located in an area where the number of inhabitants increased;

- type of school management $(\tau=0.022 ; p<0.01)$ : Pedagogical supervision was shown to increase when the school was privately managed.

Weak, negative, but significant correlations were found between the principals' career development supervision they gave to their teachers and:

- Training in School administration or principal training programme or course $(\tau=-0.054 ; p<0.01)$ : The principal's career development supervision decreased when the principal had been trained in School administration or principal training programme or course before and/or after becoming principal. 
- Formal education/Teacher training/education programme or course $(\tau=$ $-0.058 ; p<0.01)$ : Career development supervision decreased when the principal had Formal education/Teacher training/education programme or course before and/or after becoming principal.

- Formal education/Instructional leadership training or course ( $\tau=-0.055 ; p<$ 0.01): Career development supervision decreased when the principal had Formal education/Instructional leadership training or course before and/or after becoming principal.

However, the principals' career development supervision was shown to increase when these school leaders:

- had no training in School administration or principal training programme or course before and/or after becoming principal;

- had no Formal education/Teacher training/ education programme or course before and/or after becoming principal;

- had no Formal education/Instructional leadership training or course.

Weak, positive, but significant correlations were observed between the principals' career development supervision and:

- Students' linguistic diversity $(\tau=0.068 ; p<0.01)$ : Career development supervision for the teachers increased when the students linguistic diversity increased;

- Schools location ( $\tau=0.056 ; p<0.01)$ : Career development supervision increased when the school was located in an area where the number of inhabitants increased;

- Type of school ( $\tau=0.087 ; p<0.01$ ): Career development supervision increased when the school was privately managed.

Weak, negative, and significant correlations were found between Students linguistic diversity and:

- Formal education/Teacher training/education programme or course $(\tau=$ $-0.061 ; p<0.01)$ : The students' linguistic diversity decreased when the principal had acquired Formal education/ Teacher training/ education programme or course before and/or after becoming principal;

- Formal education/Instructional leadership training or course ( $\tau=-0.048 ; p<$ 0.01 ): The students linguistic diversity at school was shown to decrease when the principal had acquired Formal education/Instructional leadership training or course before and/or after becoming principal.

However, the students linguistic diversity was shown to increase when:

- administrative supervision decreased;

- the principals had no Formal education/Teacher training/education programme or course before and/or after becoming principal;

- the principal had no Formal education/Instructional leadership training or course.

Weak, positive, and significant correlations were observed between Students linguistic diversity and the following:

- Schoofs location $(\tau=0.101 ; p<0.01)$ : Students' linguistic diversity increased 
when the school was located in an area where the number of inhabitants increased;

- Type of school ( $\tau=0.060 ; p<0.01)$ : Students linguistic diversity increased in the case of privately managed schools;

- Experience as principal in this school $(\tau=0.035 ; p<0.01)$ : Students' linguistic diversity increased when the number of years of experience as principal in the school increased.

No correlation was found between the principals' administrative supervision and:

- their experience as principal in this school;

- their overall experience as principal.

No correlation was found between the principals' pedagogical supervision and:

- their career development supervision;

- the students' linguistic diversity,

- their overall experience as principal.

No correlation was found between the principals' career development supervision and:

- their gender,

- their experience as principal in this school;

- their overall experience as principal.

No correlation was found between the students linguistic diversity and:

- the principal's gender;

- the principal's overall experience as principal.

From these results, we gathered that except for the principals' pedagogical supervision, their administrative supervision and career development supervision correlated with the students' linguistic diversity and thus constituted our variables of interest for multiple regression analysis.

\section{Discussion and Conclusion}

Research acknowledges the significant impact of principals' practices on working conditions and on teacher supervision and the professional development supervision they give their teachers (Leithwood et al., 2004; Leithwood \& Jantzi, 2006, 2008). In light of this observation, we demonstrated the relevance of analyzing the supervision and supervision practices of school leaders in OECD countries in terms of administrative supervision, pedagogical supervision, and professional development facilitation.

Our factor analyses enabled us to identify three factors among 17 items pertaining to different forms of supervision practices principals use to help their teachers (Questions 21 and 29), namely, administrative supervision, pedagogical supervision, and career development supervision. Our main findings thus concern the principals' teacher supervision practices and sociodemographic and socioprofessional characteristics, as well as the contexts of their schools and their 
students.

The correlation analysis results reveal that when students' linguistic diversity was evidenced, the principals provided less administrative supervision to their teachers by being less involved in: solving problems related to the lessons timetable; collaborating with teachers to solve discipline problems in class; checking for mistakes in the schoof s procedures, providing parents or guardians with information; and supporting co-operation among their teachers.

On the other hand, the principals showed a greater level of career develop supervision by engaging more in: change in a teacher's salary or a payment of a financial bonus, change in the likelihood of a teacher's career advancement, material sanctions such as reduced annual increases in pay are imposed; change in a teacher's work responsibilities, and dismissal or non-renewal of contract following assessments.

Thus, in this study, the presence of student linguistic diversity translated to a decrease in the amount of administrative supervision the principals offered their teachers, while the absence of such diversity resulted in an increase in the amount of administrative supervision they provided. In other words, linguistic diversity slowed the manifestation of the principals' administrative supervision. This observation concurs with other findings showing that this context indeed creates numerous additional challenges for both teachers and principals (Bouchamma, 2008, 2009, 2015; Bouchamma \& Tardif, 2011; Castles et al., 2002; Marks \& Printy, 2003; Somers, 2018; Zetter et al., 2006).

Our results also show that the presence of student linguistic diversity explained the increase in the amount of career development supervision provided by the principals. This added element thus represents an opportunity for school leaders to augment the profession development supervision they give to their teachers. This finding is in agreement with those of other authors (OECD, 2018; Panagiotopoulou \& Rosen, 2018; Robinson, 2007; Somers, 2018) arguing that the presence of linguistic diversity in schools may create opportunities for principals to collaborate with their teachers on which of the principals' supervision practices have the most impact on teaching and student achievement.

Our results show that in a context of linguistic diversity, principals received less continuous professional development (before and/or after their entry) in teaching or pedagogy, compared to their counterparts in schools where diversity is absent. This lack of training means that their administrative support to teachers decreases and their support for their career prospects becomes more present.

\section{Implications and Future Considerations}

In this study on the teacher supervision practices of school leaders in OECDmember countries, we show that in the presence of student linguistic diversity, the principals provided less administrative supervision to their teachers. We recall that the first factor emerging from our factor analyses was composed of five factors: 1) Resolved problems with the lessons timetable; 2) Collaborated with 
teachers to solve discipline problems in class; 3) Checked for mistakes in school procedures; 4) Provided parents or guardians with information; and 5) Supported co-operation among teachers.

Our findings thus concur with those of other studies highlighting the importance of considering the dimension of diversity in the competency standards of school leaders (Lambert \& Bouchamma, 2019). Our results also show that student linguistic diversity is not a hindrance to teacher professional development; on the contrary, in schools where linguistic diversity is evidenced, principals are the best prepared to supervision the professional career development perspectives of their teachers through their positive influence in such areas as: change in a teacher's salary or a payment of a financial bonus, change in the likelihood of a teacher's career advancement, material sanctions such as reduced annual increases in pay are imposed; change in a teacher's work responsibilities, and dismissal or non-renewal of contract following assessments.

School principals in a context of diversity tend, on the one hand to attach more importance to the performance and quality of teacher's outcome than to their professional development (Nolan \& Hoover, 2008) and, on the other hand, to use inappropriate means in the supervision of teachers (Appave and David, 2017; Panagiotopoulou \& Rosen, 2018; Somers, 2018; OECD, 2018). Also, in a context of diversity, their administrative tasks are amplified (Marks \& Printy, 2003; Bouchamma, 2005, 2008, 2011; Banks \& Mcgee Banks, 2010) which, according to our results, are in overcrowded places.

Finally, using the TALIS 2013 data, this study enabled us to analyze several contextual aspects of the schools and their students as well as the sociodemographic and socio-professional characteristics of the principals in a context of linguistic diversity. That said, with ever-increasing numbers of new arrivals in OECD countries, it goes without saying that the TALIS 2018 data disseminated during this study paints a more relevant portrait of the current situation.

\section{Conflicts of Interest}

The authors declare no conflicts of interest regarding the publication of this paper.

\section{References}

Appave, G., \& David, I. (2017). Integration That Values Diversity-Exploring a Model for Current Migration Dynamics. In M. McAuliffe, \& M. Klein Solomon (Eds.), Migration Research Leaders' Syndicate: Ideas to Inform International Cooperation on Safe, Orderly and Regular Migration (pp. 159-167). Geneva: OIM.

Banks, J. A., \& McGee Banks, C. A. (2010). Multicultural Education: Issues and Perspectives (7th ed.). Hoboken, NJ: John Wiley \& Sons Inc.

Bouchamma, Y. (2005). Evaluating Teaching Personnel. Which Model of Supervision Do Canadian Teachers Prefer? Journal of Personnel Evaluation in Education, 18, 289-308. https://doi.org/10.1007/s11092-007-9025-8

Bouchamma, Y. (2008). Les défis de l'école en milieu minoritaire francophone face à 
l'intégration des élèves immigrants. Thèmes canadiens (printemps), 120-123.

Bouchamma, Y. (2011). Écoles efficaces: quelles compétences des directions d'école en matière d'accompagnement du personnel enseignant? In M. Moldoveanu (Ed.), Les compétences des acteurs de l'éducation (pp. 19-36). Montréal: Éditions Peisaj.

Bouchamma, Y. (2015). L'école et l'immigration-Défis et pratiques gagnantes. Caraquet: Les éditions de la Francophonie.

Bouchamma, Y., \& Tardif, C. (2011). Les pratiques des directions d'écoles en contexte de diversité ethnoculturelle. In F. Kanouté \& G. Lafortune (Eds.), Familles québécoises d'origine immigrante: Les dynamiques de l'établissement (pp. 87-96). Montréal: Presses de l'Université de Montréal. https://doi.org/10.4000/books.pum.8912

Branch, G. F., Hanushek, E. A., \& Rivkin, S. G. (2012). Estimating the Effect of Leaders on Public Sector Productivity: The Case of School Principals (No. w17803). Cambridge, MA: National Bureau of Economic Research.

Brown, K. E., \& Medway, F. J. (2007). School Climate and Teacher Beliefs in a School Effectively Serving Poor South Carolina (USA) African-American Students: A Case Study. Teaching and Teacher Education, 23, 529-540.

https://doi.org/10.1016/j.tate.2006.11.002

Castles, S. (2010). Understanding Global Migration: A Social Transformation Perspective. Journal of Ethnic and Migration Studies, 36, 1565-1586. https://doi.org/10.1080/1369183X.2010.489381

Castles, S., Korac, M., Vasta, E., \& Vertovec, S. (2002). Integration: Mapping the Field. Home Office Report by the University of Oxford Centre for Migration and Policy Research and Refugee Studies Centre, Immigration Research and Statistics Service.

Cohen, J. (1992). Statistical Power Analysis. Current Directions in Psychological Science, 1, 98-101. https://doi.org/10.1111/1467-8721.ep10768783

Cohen, J. (2013). Statistical Power Analysis for the Behavioral Sciences. Cambridge: Academic Press. https://doi.org/10.4324/9780203771587

Collerette, P., Pelletier, D., \& Turcotte, G. (2013). Recueil de pratiques des directions d'écoles secondaires favorisant la réussite des élèves. Gatineau: Université du Québec en Outaouais.

Commission Européenne (2018). Special Eurobarometer 469. Integration of Immigrants in the European Union.

http://www.europeanmigrationlaw.eu/documents/EuroBarometer-IntegrationOfMigra ntsintheEU.pdf

Cotton, K. (2003). Principals and Student Achievement: What the Research Says. Alexandria, VA: Association for Supervision and Curriculum Development (ASCD).

Czaika, M., \& De Haas, H. (2014). The Globalization of Migration: Has the World Become More Migratory? International Migration Review, 48, 283-323.

https://doi.org/10.1111/imre.12095

De Witte, M. (2018). Stanford Research Explores the Complexities of Global Immigration. https://news.stanford.edu/2018/04/18/examining-complexities-migration/

Demireva, N. (2017). Immigration, Diversity and Social Cohesion. Briefing. The Migration Observatory, Oxford: University of Oxford.

DuFour, R., DuFour, R. B., Eaker, R. E., \& Karhanek, G. (2004). Whatever It Takes: How Professional Learning Communities Respond When Kids Don't Learn.

https://staffweb.psdschools.org/cshaw/May\%2030,\%202013/Other/How\%20PLCs\%20R espond\%20When\%20Kids\%20Don't\%20Learn.pdf

Goldin, I., Cameron, G., \& Balarajan, M. (2011). Exceptional People: How Migration 
Shaped Our World and Will Define Our Future. Princeton, NJ: Princeton University Press. https://doi.org/10.1515/9781400836291

Hall, K., \& Posel, D. (2019). Fragmenting the Family? The Complexity of Household Migration Strategies in Post-Apartheid South Africa. IZA Journal of Development and Migration, 10, No. 2. https://doi.org/10.2478/izajodm-2019-0004

Hallinger, P., \& Heck, R. H. (1998). Exploring the Principal's Contribution to School Effectiveness: 1980-1995. School Effectiveness and School Improvement, 9, 157-191. https://doi.org/10.1080/0924345980090203

Koser, K. (2016). International Migration: A Very Short Introduction. Oxford: Oxford University Press. https://doi.org/10.1093/actrade/9780198753773.001.0001

L'Hostie, M., \& Boucher, L.-P. (2004). L'accompagnement en éducation: Un soutien au renouvellement des pratiques. Québec: PUQ. https://doi.org/10.2307/j.ctv18ph4nc

Lambert, M., \& Bouchamma, Y. (2019). The Development of Competencies Required for School Principals in Quebec: Adequacy between Competency Standard and Practice. Education Policy Analysis Archives, 27, 116. https://doi.org/10.14507/epaa.27.4211

Lapointe, P., \& Archambault, J. (2005). L'engagement des directions dans la gestion pédagogique de l'école. Le point sur le monde de l'éducation, 16, 50-51.

Leithwood, K., \& Jantzi, D. (2006). Transformational School Leadership for Large-Scale Reform: Effects on Students, Teachers, and Their Classroom Practices. School Effectiveness and School Improvement, 17, 201-227.

https://doi.org/10.1080/09243450600565829

Leithwood, K., \& Jantzi, D. (2008). Linking Leadership to Student Learning: The Contributions of Leader Efficacy. Educational Administration Quarterly, 44, 496-528. https://doi.org/10.1177/0013161X08321501

Leithwood, K., Harris, A., \& Hopkins, D. (2008). Seven Strong Claims about Successful School Leadership. School Leadership and Management, 28, 27-42. https://doi.org/10.1080/13632430701800060

Leithwood, K., Seashore, L., Anderson, S., \& Wahlstrom, K. (2004). How Leadership Influences Student Learning. New York: The Wallace Foundation.

Marks, H. M., \& Printy, S. M. (2003). Principal Leadership and School Performance: An Integration of Transformational and Instructional Leadership. Educational Administration Quarterly, 39, 370-397. https://doi.org/10.1177/0013161X03253412

Marshall, K. (2005). It's Time to Rethink Teacher Supervision and Evaluation. Phi Delta Kappan, 86, 727-735. https://doi.org/10.1177/003172170508601004

Marzano, R., Waters, T., \& McNulty, B. (2005). School Leadership That Works: From Research to Results. Alexandria, VA: Association for Supervision and Curriculum Development.

McAndrew, M. (2001). Immigration et diversité à l'école, le débat québécois dans une perspective comparative. Montréal: Les Presses de l'Université de Montréal. https://doi.org/10.4000/books.pum.15514

Newland, K. (2017). Migrant Return and Reintegration Policy: A Key Component of Migration Governance. In M. McAuliffe, \& M. Klein Solomon (Eds.), Migration Research Leaders' Syndicate: Ideas to Inform International Cooperation on Safe, Orderly and Regular Migration (pp. 169-173). Geneva: OIM.

Nolan, J. F., \& Hoover, L. A. (2008). Teacher Supervision and Evaluation: Theory into Practice (2nd ed.). Hoboken, NJ: Wiley.

Northouse, P. G. (2012). Leadership: Theory and Practice. Thousand Oaks, CA: Sage 
Publications.

OECD (2018). The Resilience of Students with an Immigrant Background: Factors That Shape Well-Being. Paris: OECD Publishing. https://doi.org/10.1787/9789264292093-en

Panagiotopoulou, J. A., \& Rosen, L. (2018). Denied Inclusion of Migration-Related Multilingualism: An Ethnographic Approach to a Preparatory Class for Newly Arrived Children in Germany. Language and Education, 32, 394-409. https://doi.org/10.1080/09500782.2018.1489829

Pont, B., Nusche, D., \& Moorman, H. (2008). Improving School Leadership, Volume 1: Policy and Practice. Paris: OECD Publishing. https://www.oecd.org/education/school/44374889.pdf

Robinson, V. M. (2007). School Leadership and Student Outcomes: Identifying What Works and Why. Strawberry Hills: Australian Council for Educational Leaders.

Robinson, V. M., Lloyd, C. A., \& Rowe, K. J. (2008). The Impact of Leadership on Student Outcomes: An Analysis of the Differential Effects of Leadership Types. Educational Administration Quarterly, 44, 635-674. https://doi.org/10.1177/0013161X08321509

Sergiovanni, T. J., \& Starratt, R. J. (2013). Supervision: A Redefinition (9th ed.). Boston, MA: McGraw-Hill Higher Education.

Silva, D. Y., \& Dana, N. F. (2001). Collaborative Supervision in the Professional Development School. Journal of Curriculum and Supervision, 16, 305-321.

Silver, H. (2015). The Contexts of Social Inclusion. United Nations Department of Economic and Social Affairs, Working Document No. 144, ST/ESA/2015/EWP/144. https://doi.org/10.2139/ssrn.2641272

Somers, T. (2018). Multilingualism for Europeans, Monolingualism for Immigrants? Towards Policy-Based Inclusion of Immigrant Minority Language Students in Content and Language Integrated Learning (CLIL). European Journal of Language Policy, 10, 203-228. https://doi.org/10.3828/ejlp.2018.12

Spanneut, G. (2010). Professional Learning Communities, Principals and Collegial Conversations. Keppa Delta Pi Record, 46, 100-103. https://doi.org/10.1080/00228958.2010.10516704

Triandafyllidou, A. (Ed.) (2018). Globalisation and Migration. In Handbook on Migration and Globalisation (pp. 1-13). Toronto: Edward Elgar Publishing. https://doi.org/10.4337/9781785367519

UNESCO (2017). Education for Sustainable Development Goals: Learning Objectives. Paris: Division for Inclusion, Peace and Sustainable Development, Education Sector.

Zetter, R., Griffiths, D., Sigona, N., Flynn, D., Pasha, T., \& Beynon, R. (2006). Immigration, Social Cohesion and Social Capital: What Are the Links? Oxford: Joseph Rowntree Foundation, Oxford University. 